\title{
WPS3410
}

\section{Pension Funds and National Saving}

\author{
Pablo Lopez Murphy and Alberto R. Musalem*
}

August 24th, 2004

\begin{abstract}
We conduct an empirical study of the effect of the accumulation of pension funds financial assets on national saving. To do that we rely on a panel of 43 countries including several developed and developing countries. We find evidence suggesting that the accumulation of pension funds financial assets might increase national saving when these funds are the result of a mandatory pension program. In contrast, national saving might be unaffected when pension funds are the result of a public program implemented to foster voluntary pension saving.
\end{abstract}

Keywords: National saving, pension funds, mandatory

JEL classification: E21, G23, H55

*Pablo Lopez Murphy (pmurphy1@worldbank.org) is a Consultant, Alberto R. Musalem (amusalem@worldbank.org) is Lead Economist, both in the MENA Region of the World Bank. The views expressed in this paper are ours only and do not necessarily represent those of The World Bank. We thank the support from the World Bank Research Support Budget to do this work. We also thank Robert Holzmann and Robert Palacios for useful comments. The usual caveat applies. 


\section{Introduction}

This paper asks the following question: does the accumulation of pension funds financial assets stimulate national saving? In other words, is the accumulation of pension financial assets helpful to foster national saving?

Having an answer for this question might be useful for several reasons. First, due to pervasive aging problems, several developed countries are debating reforms in their pay as you go pension systems. In fact, The Economist (2004) alerts that a larger generation of old people will need support from a population of young people that is shrinking continuously in absolute size. One of the options available to face this fact is to reduce the role of the pay as you go system and encourage funding. In that scenario, a careful understanding of the macroeconomic consequences of accumulating pension funds might be of central interest.

Second, high saving rates typically go hand in hand with high and persistent investment rates. It is well known that the accumulation of productive factors is one of the key engines for a sustained growth process. In this respect, an influential paper by Young (1995) even argues that behind the famous East Asian "miracle" there was no miracle at all: the key in achieving per capita gdp annual growth rates averaging almost 7 percent in a span of more than two decades was an impressive accumulation of productive factors. If one were able to show that pension funds increase national saving, then the design of pension regimes might have important policy implications.

In this paper we answer the above questions using regression analysis, by relying on what we believe is the largest cross country time series data on pension funds financial assets constructed up to now. National saving regressions 
are estimated for a sample comprising 43 countries including both OECD members and developing nations totalizing more than 400 observations. We estimate our empirical equations using various panel data techniques to deal with several important econometric issues such as: simultaneity and country heterogeneity.

Although the main national saving determinant that we are focused on is pension funds, a by-product of the paper is that we also consider other saving determinants. Thus, we present evidence related to questions repeatedly tackled in the saving literature such as: Does income growth raise national saving? Do higher interest rates lead to higher national saving? Does national saving vary with a country's income level? Do demographic factors influence national saving? Is there a terms of trade effect on national saving?

The main finding of the paper is that the impact of pension funds depends on whether these funds are mandatory or voluntary. More precisely, the evidence suggests that increases in pension funds financial assets increase national saving when pension funds are the result of a mandatory pension program. In contrast, changes in pension funds financial assets do not have a significant effect on national saving when pension funds are accumulated in response to a public program designed to promote voluntary saving.

The rest of the paper is organized as follows. Section 2 discusses theoretical considerations that have to be taken into account when studying the effects of pension funds on aggregate saving. Section 3 reviews some of the existing empirical estimations. Section 4 presents econometric modeling issues with a detailed explanation of the controls that will be used to identify the effect of pension funds on national saving. Section 5 describes our data 
base and the sources employed. Section 6 reports the econometric methods that were used to estimate the econometric model and the corresponding results that were obtained. Section 7 concludes.

\section{Theoretical Considerations}

\subsection{Individual level}

The most useful framework to study the effect of mandatory pension programs on saving at a microeconomic level is the simple life cycle model that is discussed in detail in, for example, Atkinson and Stiglitz (1980). The individual lives for two periods, in the first of which he/she earns a wage from his/her fixed labor supply and in the second he/she is retired. He/she saves from his wage income to provide for second period consumption with a constant rate of interest (i.e., the rate of interest does not vary with his/her level of saving).

The main insight that is obtained from the model is that of consumption smoothing: the individual will save to transfer purchasing power to the stage of his/her life in which he/she is retired.

The introduction of a mandatory pension program means that a tax falls on wages in the first period to pay retirement benefits in the second period. Net pension wealth is simply defined as the difference between the present value of benefits minus the value of contributions. As emphasized by Liebman and Feldstein (2001), the value of net pension wealth plays a key role in understanding the effect of a mandatory pension program on individual saving. 
If net pension wealth is zero, the intertemporal budget constraint of the individual does not change. The individual would reduce his/her ordinary saving (i.e., saving in non-pension instruments) by exactly the same amount of his/her pension contribution leaving his/her total saving unchanged. However, if net pension wealth is positive, the intertemporal budget constraint is relaxed and consumption in each period would rise. The individual would reduce his/her ordinary saving by more than the amount of his/her pension contribution and thus, diminishing his/her total saving. Finally, if net pension wealth is negative, the intertemporal budget constraint is tightened and consumption in each period would fall. The individual would reduce his/her ordinary saving by less than the amount of his pension contribution, hence his/her total saving would increase.

From the previous paragraph the reader might think that the saving response (at a microeconomic level) to mandatory pension programs is completely determined by the value of net pension wealth. However, things become more complicated if we relax the assumptions (some of them implicit) of the simplest life cycle model that we made above. We will go through several examples assuming that net pension wealth is zero or, equivalently, examples in which ordinary saving should be reduced by the same amount of pension contributions leaving total saving unaffected.

First, suppose that the mandatory pension program provides benefits that are larger than the level of consumption that is desired by the individual in the second period of his/her life in the absence of the program. Suppose in addition that there are borrowing constraints. ${ }^{1}$ If for some reason (e.g., lack

\footnotetext{
${ }^{1}$ Flemming (1973) offers one of the first formalizations of the life cycle model with
} 
of collateral) there are borrowing constraints, then the individual will reduce his/her ordinary saving to zero. Note that the individual would like to reduce his/her ordinary saving even further (i.e., to borrow) so as to restore his/her desired level of future consumption but binding borrowing constraints do not allow such response. The bottom line is that binding borrowing constraints result in ordinary saving falling by less than the amount of pension contributions, hence total saving increases.

Second, suppose that the mandatory pension program induces the individual to retire earlier than they would have as suggested by Feldstein (1974). Saving during working years will have to be higher to finance a longer retirement. Again, ordinary saving will fall by less than the amount of pension contributions, therefore, his/her total saving increases.

Third, imagine that workers save not only for consumption smoothing motives but also for precautionary motives (e.g., extraordinary health expenditures). ${ }^{2}$ Since pension wealth is highly illiquid, then it is a poor substitute of precautionary wealth. In those circumstances, ordinary saving will fall by less than the amount of pension contributions, therefore, total saving will increase.

Fourth, suppose that an important driver of saving is that people want to leave an inheritance to their children. ${ }^{3}$ Again, due to low substitutability, ordinary saving will fall by less than the amount of pension contributions, capital market imperfections (e.g., borrowing constraints).

${ }^{2}$ Carrol (1997), for example, presents survey evidence in which people predominantly say that being prepared for emergencies is the most important reason for saving.

${ }^{3}$ In a famous study, Kotlikoff and Summers (1981) show that bequests account for a substantial fraction of U.S. aggregate capital accumulation. 
then his/her total saving will increase.

Finally, consider an alternative approach to the fully rational life cycle model. Thaler (1990) suggests that lots of people take consumption and saving decisions following rules of thumb instead of following "sophisticated" lifetime considerations. In those cases, ordinary saving will not be responsive to pension contributions.

\section{$2.2 \quad$ Aggregate level}

We see that figuring out the effect of a mandatory pension program on saving at a microeconomic level is not straightforward. Our previous discussion showed that there are several possibilities depending on the assumptions made. New difficulties appear when one wants to disentangle the effect of a mandatory pension program on saving at a macroeconomic or aggregate level. What we have to do is to sum the saving response of each individual but taking into account that individual responses might vary due to differences in preferences (e.g., differences in patience) or differences in opportunities (e.g., differences in net pension wealth).

The most natural analytical framework to study the effect of mandatory pension programs on aggregate saving is the overlapping generations model with production due to Diamond (1965). In such a framework, each individual lives for just two periods. In the first of which he/she earns a wage from his/her fixed labor supply and in the second he/she is retired. Second period consumption is equal to capital accumulated and capital services (i.e., interest payments). At each date is born a cohort of individuals and the population grows at a constant rate. Individuals in each cohort are identical 
and individuals across cohorts are identical except for their date of birth. The economy has a single consumption good that must be produced from capital and labor. Capital saved in one period becomes an input in the production process of the following period and it is physically identical to the consumption good. Individuals may be thought of as workers in youth and entrepreneurs in old age.

The existence of capital as a store of value is what allows individuals to carry purchasing power from the first period to the second period in the aggregate (i.e., to save). Net borrowing will be zero in the aggregate. ${ }^{4}$

It should be emphasized that in the relatively simpler pure exchange version of the overlapping generations model, as the one considered by Samuelson (1958), each individual lives for just two periods and has an endowment of the non-storable consumption good in each period. There is no production. The drawback of this version of the model is that aggregate saving is necessarily equal to zero. Why? The members of a cohort might be eager to trade present consumption for future consumption to smooth consumption along the life cycle. However, if we assume that all the members of a cohort are identical, then all members will try to do the same and individual autarchy cannot be avoided.

Moreover, even if we relax the assumption of identical individuals among the members of a generation by introducing differences in individual endowments or differences in rates of time preference, aggregate borrowing/lending cannot take place. In other words, although someone relatively more patient

\footnotetext{
${ }^{4}$ Intergenerational borrowing/lending is not possible because members of different generations meet only once in a two period life cycle.
} 
lends to someone relatively more impatient, aggregate net lending will be necessarily equal to zero. The individuals do not have a mean (e.g., capital, durable goods, money, etc.) to carry purchasing power from the first period to the second period in the aggregate.

Thus, given that there cannot be aggregate saving, studying the effects of mandatory pension programs on aggregate saving in a pure exchange version is not very useful. So we will next analyze the effect of mandatory pension programs having in mind an overlapping generations model with production.

\subsection{Fully funded programs}

There are two polar ways to run a mandatory pension program. In a fully funded program each worker makes contributions to a pension plan which are invested (i.e., used to accumulate capital). The contributions of the individuals when young are returned as capital when they are old.

A fully funded system forces each worker to save in an amount at least equal to his/her mandatory saving contribution. If, in the absence of a mandatory pension program, all individuals choose to save more than the mandatory pension contribution then, a fully funded program will simply replace ordinary saving by an equivalent amount of saving by the mandatory pension program. In these special circumstances, the mandatory pension program will be neutral with respect to total aggregate saving in the economy.

In contrast, if in the absence of a mandatory pension program all individuals choose to save less than the mandatory pension contribution, a fully funded system will augment total aggregate saving in the economy. Ordinary aggregate saving will be reduced to zero but total aggregate saving 
will increase. Note that each of the individuals would like to reduce his/her ordinary saving even further (i.e., to borrow) when young but that cannot happen in the aggregate. The individuals only have capital as a mean to transfer purchasing power across time and capital holdings can be zero but not negative.

\subsection{Pay as you go programs}

In a pay as you go program, young individuals contribute a fraction of their wage to a pool of funds out of which the elderly draw pensions. The mandatory pension program does not invest the contributions since they are automatically destined to the retirees. The rate of return of contributions is given by the rate of growth of the labor force. ${ }^{5}$ With a pay as you go program in operation, any effect that the existence of the program has upon ordinary saving is reflected in total saving since, by definition, the program does not save (i.e., accumulate capital).

To gauge the impact of a pay as you go pension program on saving one has to realize, as clearly explained by Myles (1995), that it leads to an intergenerational reallocation of resources/wealth. ${ }^{6}$ If we constraint ourselves to the case where economies have finite aggregate wealth, intergenerational re-

\footnotetext{
${ }^{5}$ The mandatory pension program pays a rate of return equal to the population growth rate because in each period there are more people alive to make contributions to the pension program. It should be remarked that in our analytical framework we are abstracting from productivity growth.

${ }^{6}$ In contrast, a fully funded program leads only to an intertemporal reallocation for each generation.
} 
allocations of wealth cannot be Pareto efficient. ${ }^{7}$ In other words, an increase in wealth of one generation comes at the expense of a reduction of wealth for the rest of the generations.

The start up of a pay as you go program entails intergenerational transfers by conceding a windfall to the members of the initial generation of beneficiaries of the system (who do not contribute) at the expense of later generations. ${ }^{8}$ Since old people have a higher propensity to consume than young people, the increase in consumption of the initial generation of beneficiaries will be higher than the fall in consumption of workers. Thus, aggregate ordinary saving will fall. It can be shown then that the impact of the start up of a pay as you go program is to slow the rate of capital accumulation and reduce the steady state capital stock. ${ }^{9}$ As Engen and Gale (1997) point out, each expansion of the pay as you go program can be thought as a small start up providing a windfall to those new beneficiaries of the system with little or no previous contributions.

\subsection{Regime change}

A shift from a pay as you go to a fully funded system implies that contributions made by the currently young generation no longer go to benefits to

\footnotetext{
${ }^{7}$ Any infinite horizon economy in which resources grow faster than the rate of interest has infinite wealth. Those economies are called dynamically inefficient. In such scenario, intergenerational transfers are Pareto efficient. See Azariadis (1996) for more details.

${ }^{8}$ This dramatic simplification is a consequence of our two period analytical framework. In the real world, one can think in terms of individuals who are at the end of their working lifes, and contribute a small amount to the system while obtaining full retirement benefits. ${ }^{9}$ See Azariadis (1996) for a formal proof.
} 
the currently old generation. Therefore, there is a transition cost (i.e., the implicit debt of the pay as you go system) that someone has to bear and, as stated by Engen and Gale (1997), there are no many options: either one generation pays the cost or the cost is divided among several generations. The option that is chosen will determine the impact of the regime change on saving.

If the transition cost is allocated to individuals with higher propensity to consume then saving will increase. For example, cutting benefits to retirees would reduce aggregate consumption more than in a scenario in which the adjustment is financed by increasing taxes to workers because old people have a higher propensity to consume than young people.

In the short run, the transition cost can also be financed by issuing government debt but at some point of time taxes will have to be increased to service that debt. If that is the case, the transition cost will not be paid by current retirees and saving will fall because current retirees probably have a higher propensity to consume than current and future workers who will bear the burden of current and future taxes.

As Samwick (1999) remarks, the intergenerational allocation of the transition cost is the most important consideration to determine the effect of the regime change on saving. However, other factors may also be relevant. If the regime change entails intragenerational distributions of wealth, then saving might also change. In most cases, fully funded systems have fewer redistributional objectives than pay as you go systems. Then, the regime change implies transferring wealth from low income earners to high income earners. If high income earners have higher propensities to save than low 
income earners, then saving goes up. ${ }^{10}$

\subsection{Voluntary programs}

The usual analytical framework used to study the effect of voluntary pension programs is the same life cycle model that was used to study the effect of mandatory pension programs.

Public policies promoting voluntary pension saving are almost always modeled as a tax reduction that raises the effective real rate of interest. Using the simple life cycle model we know that, on one hand, an increase in the real interest rate makes present consumption relatively more expensive and thus, induces an increase in saving. On the other hand, a higher real interest rate means that each unit of forgone consumption is worth more units of future consumption making the individual richer and therefore, induces a fall in saving.

The total effect of an increase in the real interest rate will therefore depend on the relative strength of the first effect (i.e., the substitution effect) versus the second effect (i.e., the income effect). ${ }^{11}$

Following Besley and Meghir (1998), an alternative and probably more accurate way to model public policies promoting voluntary pension saving is to interpret them as the creation of tax favored assets where individuals can invest in them up to a specific limit. Additional saving has to be channeled

\footnotetext{
${ }^{10}$ Dynan, Skinner and Zeldes (2003) find a strong positive relationship between personal saving rates and lifetime income. In other words, they find that rich people save more.

${ }^{11}$ If preferences are homothetic the total effect of an increase in the real interest rate depends simply on whether the elasticity of substitution between consumption early in life and later in life is greater or less than unity.
} 
through other non tax favored assets. In this alternative analytical framework, Besley and Meghir shown that, even in the case where the total effect of an increase in the real interest rate is positive, the creation of tax favored assets will have an ambiguous effect on saving.

Another important issue that has to be taken into account when dealing with voluntary pension programs is the presence of a fiscal cost. Voluntary pension programs are typically implemented by allowing tax exemptions to pension fund holders. In other cases they only allow tax deferrals. The bottom line is that, for a given amount of private saving, preferential tax treatment imply lower tax revenues and thus, lower government saving.

\section{$3 \quad$ Existing Evidence}

The empirical studies estimating the effect of pensions on saving can be divided in two groups. The first group analyses the case of pay as you go schemes while the second group focuses on funded schemes. Each of

the groups can be subdivided in three categories depending on the type of data employed to conduct the estimations: time series, cross section or cross country.

We will next briefly comment on a couple of well known papers in each of the categories distinguished above. This is just to illustrate that the comparison of different studies is not straightforward since they usually measure different things. Exhaustive reviews of the literature can be found in Congressional Budget Office (1998) and in Kohl and O'Brien (1998). 


\subsection{Pay as you go-time series}

Perhaps the most famous study in all the literature is Feldstein (1974). His contribution was to extend the consumption function popularized by Ando and Modigliani (1963) to include pension wealth as one of the key determinants (the other determinants were permanent income and wealth). The estimates shown in the paper are based on aggregate annual U.S. data and a sample of almost 40 observations. Feldstein (1996) ran the same regressions of the original paper adding 20 observations. After coping with some autocorrelation issues, he obtained the following results (standard errors in parenthesis):

$$
C=641+\underset{(.06)}{.63 Y D}+\underset{(.053)}{.074 Y D_{-1}}+\underset{(.008)}{.014 W}+\underset{(.013)}{.028 S S W}
$$

where $C$ denotes the value of real per capita consumption, $Y D$ real per capita disposable income, $W$ real per capita personal wealth. The level of disposable income in the previous year is included in an attempt to approximate permanent income. The last variable is social security wealth, $S S W$, that is defined as the present value of retirement benefits. ${ }^{12}$ What are the implications of these estimates? In 1992, $S S W$ was equal to $\$ 14,246$ billion. The fall in personal saving that could be accounted by pension wealth is $.028 * \$ 14,246 \cong \$ 400$ billion. Moreover, in 1992 , pension taxes were equal to $\$ 279$ billion. Then, the fall in personal saving that could be accounted by a

\footnotetext{
${ }^{12}$ The original paper also included a measure of corporate retained earning as one of the determinants. Feldstein (1996) shows that the results remain almost invariant when this variable is included.
} 
lower permanent income is $.3 * \$ 279 \cong \$ 84$ billion. ${ }^{13}$ Thus, the total effect of the pay as you go program was to reduce personal saving by approximately $\$ 484$ billion. Since total personal saving in 1992 was $\$ 248$ billion when it could have been $\$ 732$ billion ( $=\$ 484+\$ 248)$, he concluded that the Social Security Program reduced personal saving by 66 percent.

Barro (1978) claimed that Feldstein's estimations were biased as a result of the omission of government saving as one of the determinants of the consumption function. In fact, he showed that $S S W$ was not statistically significant when government saving was included in the regression. Another important study was Leimer and Lesnoy (1982) who argued that Feldstein's findings where highly sensible to the assumptions that he made to construct the social security wealth variable. The use of reasonable alternative assumptions results in weaker estimates of the relationship between social security and personal saving.

\subsection{Pay as you go-cross section}

Cross section studies using microeconomic data were basically motivated by the small number of observations that where available when using aggregate annual time series data. Feldstein and Pellechio (1979) derived from the traditional life cycle model an equation in which the stock of accumulated wealth is a function of labor income. More precisely, they estimated the following equation:

\footnotetext{
${ }^{13}$ Note that $.3=1-(.63+.07)$ is the marginal propensity to save of permanent disposable income.
} 


$$
A_{i}=\alpha_{0}+\alpha_{1} Y L_{i}-\mu S S W_{i}+\alpha_{3} Y L_{i}^{2}+u_{i}
$$

where $A$ denotes ordinary wealth, $Y L$ denotes net of tax labor income in the final preretirement year and $S S W$ denotes social security wealth defined as the present value of retirement benefits.

Note that $\mu$ measures the effect of the stock of pension wealth on the stock of ordinary wealth. This should be taken into account when comparing the results with time series studies that usually measure the effect of the stock of pension wealth on the flow of saving. A value of $\mu=.66$, for example, would be consistent with the results obtained in Feldstein (1996).

The most pure life cycle model suggests that $\mu=1$ if net social security wealth is equal to zero. Relaxing the assumptions of the pure life cycle model, $\mu$ can take any value from greater than unity to less than zero. Using The Survey of Financial Characteristics of Consumers for 126 married couples, the point estimates indicate that $\mu$ is significantly different from zero but not significantly different from one. In other words, the estimates generally show that $\mu$ is somewhat less than unity.

By exploiting a sample of more than 2,000 observations obtained from a series of surveys of male household heads aged 45-59 conducted by the Bureau of Census, Kotlikoff (1979) used a similar econometric specification to the one employed by Feldstein and Pellechio (1979). He also included other controls in the regression such as: dummies for marriage, race, and heads who are separated, widowed, or divorced, the head and the wife's ages and the square of their ages as well as the number of family members. His results are in line with those that were obtained by Feldstein and Pellechio 
(1979).

\subsection{Pay as you go-cross country}

Saving rates differ very substantially among countries. ${ }^{14}$ Modigliani (1970) verified that the life cycle model was a useful vehicle to rationalize those differences. In fact, the basic life cycle model predicts that fast growing countries will have higher saving rates and that countries with a higher fraction of working age population will also have higher saving rates.

Feldstein (1980) extended once again the work of Modigliani by including into the analysis the role played by the varying retirement benefits that are provided by social security programs in different countries. Using a sample of 12 observations he arrived to the following results:

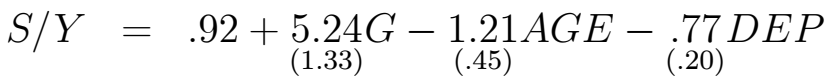

$$
\begin{aligned}
& -\underset{(.13)}{.37} B / E-\underset{(.27)}{.54 L P A G E D}
\end{aligned}
$$

where $S / Y$ is the private saving rate, $G$ is the growth rate of total private income, $A G E$ is the ratio of the number of retirees over the age of 65 to the population aged 20 to $65, D E P$ is the ratio of the number of younger dependents to the working age population, $B / E$ is the benefits-earnings replacement ratio, and $L P A G E D$ is the labor force participation rate of older men.

According to the life cycle theory we know that once we control for retirement (proxied by labor force participation of older people), higher retirement

\footnotetext{
${ }^{14}$ See Edwards (1996) for a relatively recent documentation of this fact.
} 
benefits measured by the benefits-earnings replacement ratio, $B / E$, reduce the private saving rate. The results of the regression do not reject this hypothesis.

Edwards (1996) works with a sample of 32 countries (including developed and developing countries) and a panel of more than 200 observations to study the determinants of private saving. Among them he includes a social security variable that is defined as the ratio of public expenditure on social security and welfare to total public expenditures. In all the regressions presented in his paper, the social security variable has a negative coefficient that is significantly different from zero.

\subsection{Funded programs-time series}

In contrast to the implications of the life-cycle theory, two well known cross sectional studies by Cagan (1965) and Katona (1965) have shown that employees covered by private pensions do not save less and may even save more than employees not covered by private pensions. Cagan interpreted the results by saying that pension coverage showed the importance of saving for retirement and saving could increase due to this "recognition effect". Katona had a different explanation for the phenomenon based on the idea that the effort employed to achieve a goal increases when the distance to the goal decreases. In this case the goal would be an adequate retirement consumption.

Munnel (1976) obtained completely different findings using a sample of 5,000 men who were between ages of 45 and 59 in 1996. In fact, she presented evidence showing that employees covered by private pensions save substantially less than employees not covered by private pensions. 
The previous three studies were focused on the effects of private pensions on personal saving but none of them considered the effects of private pensions on aggregate private saving. Feldstein (1978) remarked that the net effect of private pensions on private saving depended on three key issues: how do employees covered by private pensions alter their ordinary saving, the amount of anticipated pension benefits that firms effectively fund and the response of shareholders to unfunded liabilities of their firms.

Ideally one would like to measure these three responses separately. However, data limitations only allow an estimate of the aggregate response. Using aggregate annual time series data for the U.S. and a sample with almost 40 observations, he obtained the following results (standard errors in parenthesis):

$$
\begin{aligned}
S P R I V= & \underset{(.14)}{-.32}+\underset{(.06)}{.38 Y D}-\underset{(.04)}{.12 Y D_{-1}-\underset{(.006)}{.005 W} W_{-1}} \\
& -\underset{(.014)}{.033 S S W}+\underset{(.10)}{.78} R E+\underset{(.33)}{.04} S P E N
\end{aligned}
$$

where $S P R I V$ denotes per capita real private saving, $Y D$ is per capita real disposable income, $W$ is the per capita real value of wealth, $S S W$ is social security wealth, $R E$ is retained earnings of the firms and $S P E N$ is pension saving. ${ }^{15}$

Given that the coefficient of the pension saving variable is smaller than the standard error, the hypothesis that private saving is not affected cannot be rejected. One possible rationalization of this result is that employees

\footnotetext{
${ }^{15}$ Pension saving is measured as the increase in the book value of pension fund reserves during the calendar year. These pension values are also adjusted to real dollars with consumer price index and converted to per capita amounts.
} 
reduce their ordinary saving by the same amount of their contributions leaving unchanged their total asset accumulation. At the same time, the firm uses the reduction on wages to finance the pension fund without modifying retained earnings. Thus, private saving remain unchanged. ${ }^{16}$

\subsection{Funded programs-cross section}

Hubbard (1986) used cross section data collected from a survey of the U.S. President's Commission on Pension Policy in 1979 with a sample of more than 3,000 observations. The estimates imply that an increase in social security wealth of one dollar reduces ordinary wealth by thirty-three cents, while an increase in private pension wealth of one dollar reduces ordinary wealth by sixteen cents. Gale (1998) argues that most estimates of the effect of private pensions on ordinary wealth are biased downwards.

\subsection{Funded programs-cross country}

Baillu and Reisen (1997) work with a sample of 10 countries and a panel of more than 100 observations to study the determinants of private saving rates in the same fashion as Edwards (1996). The purpose of their paper is to study the effect of funded pension wealth as a determinant of private saving rates. They find systematic evidence that funded pension wealth increases private saving rates in developing countries with mandatory funded pension programs.

\footnotetext{
${ }^{16}$ Even if the firm uses the reduction in wages to distribute dividends instead of financing the pension fund, the shareholders can save those additional dividends leaving aggregate saving unchanged.
} 


\section{Econometric Modeling}

We will adopt a reduced form approach encompassing a variety of saving determinants identified in the saving literature instead of deriving a narrow model of consumption/saving decisions from first principles. This approach is followed by several papers in the cross country saving literature such as Edwards (1996), Masson, Bayoumi and Samiei (1998), and Loayza, Schmidt Hebbel and Serven (2000). However, our main focus will not be on all saving determinants but on pension saving.

The dependent variable will be the national saving rate, $n s r$. The determinant of our interest is the pension saving rate, $p s r$.

An important remark has to do with the choice of our dependent variable, the national saving rate. We could have chosen the private saving rate instead and also include the government saving rate as one of the private saving determinants. Nevertheless, following that path would have been associated with several measurement problems. For example, private saving is usually overestimated in the national accounts because it is not adjusted for the inflation tax suffered by money and nominal bond holders; the opposite happens with government saving measures. Another important measurement problem is that available government statistics do not correspond to the same level of government for each of the countries. Depending on the country, The Government Financial Statistics publishes data corresponding to the general

government, the consolidated central government, or the budgetary central government. These problems do not appear when we work with the national saving rate.

As clearly explained by Loayza, Schmidt Hebbel and Serven (2000), when 
we use the same determinants for national saving rates and private saving rates we are assuming that public saving is determined by the same variables that determine private saving. This is a standard practice given that there is almost no theoretical work trying to explain the behavior of government saving.

Following the cross country saving literature we consider the following controls:

- old dependency ratio, odr. Following the life cycle model of consumption and saving of Ando and Modigliani (1963) we know that saving behavior changes dramatically in the different stages of the life cycle. For example, when people reach retirement, their labor income vanishes and they start to dissave. Therefore, we interpret a relatively high value of odr as an economy with a relatively high proportion of dissavers relative to savers. Naturally, we expect a negative coefficient for $o d r$.

- young dependency ratio, $y d r$. As with odr we also expect a negative coefficient. Leff (1969) was the first paper documenting the relationship between national saving rates and dependency rates using a sample of 74 countries. He said that children represent a heavy charge to expenditure which in national accounts enter under the heading of consumption. Because they contribute to consumption but not to production, a high ratio of dependents to the working age population might be expected to impose a constraint on a society's potential for saving.

- urbanization ratio, ur. If people have a precautionary motive for sav- 
ing, we would expect that those who face more uncertainty will save more. In the aggregate, countries relying heavily on agriculture will be exposed to more climate uncertainty. Since a higher urbanization ratio is associated with a lower predominance of agricultural activities we would expect a negative coefficient for ur. A different interpretation is discussed below.

- terms of trade, tot. An old proposition in open macroeconomics is that an improvement in terms of trade results in an increase in saving. This idea is associated to the names of Harberger, Laursen and Metzler since the early 1950s. The logic of the proposition goes as follows. An improvement in the terms of trade raises a country's real income level, measured as the purchasing power of its exports in world markets, and hence, on the assumption that the marginal propensity to consume is less than unity, raises saving. The theoretical proposition was revisited and qualified by Svensson and Razin (1983) and many others. ${ }^{17}$ Ostry and Reinhart (1992) show some empirical evidence for developing countries.

- income, $g d p$. In a scenario where subsistence considerations are pervasive there is little margin for saving considerations. See Rebelo (1992) for a model in which subsistence considerations play a role in consumption-saving decisions. Thus, we expect a positive coefficient for $g d p$.

\footnotetext{
${ }^{17}$ Svensson and Razin emphasized that a distinction has to be made between temporary and permanent terms of trade shocks. Only temporary terms of trade shocks had an effect on saving.
} 
- income growth, growth. In a stagnant economy, saving of active people is compensated by dissaving of passive people. In contrast, in a growing economy, saving of active people more than compensates dissaving of passive people. Thus, we expect a positive coefficient for growth.

- real interest rate, $r$. An increase in the real interest rate will affect individual saving through two different forces that work in opposite directions. On one hand, it will make present consumption more expensive inducing an increase in saving. On the other hand, it will make possible the transformation of a given amount of present consumption into more units of future consumption inducing a fall in saving. In addition, there is no easy answer on the way in which an increase in the real interest rate will affect government and/or firms saving. ${ }^{18}$

- inflation, $\pi$. Inflation has an ambiguous effect on saving. Higher inflation is associated to higher macro uncertainty that could stimulate precautionary saving. ${ }^{19}$ At the same time, higher inflation induces a substitution away from financial assets due to a lower real return.

- financial deepening, $f d$. It intends to capture a measure of the vehicles available to save. Better functioning financial markets might foster saving. Thus, the expected coefficient is positive.

- foreign saving ratio, $f s r$. In a world with perfect capital mobility across countries, foreign saving would be a result of national saving and not

\footnotetext{
${ }^{18}$ Ogaki, Ostry and Reinhart (1996) quantify empirically the response of consumption/saving to changes in the real rate of interest.

${ }^{19}$ Risk-averse households will react to increased uncertainty by increasing their saving.
} 
a determinant. However, the world is more accurately characterized by scenarios where foreign borrowing is rationed. The expected sign of the coefficient is negative. According to Rahman (1968), an increase in foreign funds causes a relaxation of government saving and thus a reduction of the national saving rate.

- social expenditure ratio, ser. Using the life cycle model we know that higher retirement benefits reduce saving needs. The expected coefficient is negative.

\section{$5 \quad$ Data and Sources}

Our data set comprises a maximum of 43 countries and spans the years 19602002. This panel data set is heavily unbalanced since the number of time series observations differs considerably across countries.

The dependent variable in our regressions will be the national saving rate, nsr. Following Loayza, Lopez, Schmidt Hebbel and Serven (1998), nsr is defined as the ratio between gross national saving, gns, and gross national disposable income, gndi.

Gross national disposable income, gndi, is defined as gross national income, gni, plus current transfers from abroad, tr. Gross national income, $g n i$, is defined as gross domestic product, $g d p$, plus net factor payments from abroad, $n f p a .{ }^{20}$ Gross national saving, gns, is equal to the difference be-

${ }^{20}$ All $g d p$ estimates are based on the production approach. There usually exists a discrepancy between $g d p$ estimates based on the production approach and $g d p$ estimates based on the expenditure approach. 
tween gndi and total consumption, tc. Total consumption, tc, is the sum of household final consumption expenditure, $h c$, and general government final consumption expenditure, te. ${ }^{21}$ All the variables are measured in local currency at current prices. The source used to obtain annual time series of each of the variables was The World Development Indicators. ${ }^{22}$

The main determinant of our interest is the pension saving rate, psr. It is defined as the ratio between pension saving, ps, and gross national disposable income, gndi. Pension saving is defined as the change in the value of financial assets of pension funds, $p a$. Annual time series showing the evolution of pension assets were basically obtained from national sources and from The Institutional Investors Statistical Yearbook. ${ }^{23}$

Following Impavido, Musalem and Tressel (2003) we divide the countries between two groups. The first group comprises the countries in which our data on pension assets are predominantly (i.e., more than 50 percent) the result of mandatory funded pension programs. The second group includes the countries in which our data on pension assets are predominantly the result of voluntary funded pension programs. In the first group we have: Argentina, Bolivia, Bulgaria, Chile, Colombia, Costa Rica, Egypt, El Salvador, Hungary, India, Jordan, Kazkhstan, Malaysia, Mexico, Morocco, Nepal, Panama, Peru, Philippines, Poland, Singapore and Uruguay. In the second group we have:

\footnotetext{
${ }^{21}$ Total consumption includes the statistical discrepancy that results from estimating $g d p$ using the expenditure and output approach.

${ }^{22}$ All the series were downloaded electronically through the World Bank's internal database system, SIMA.

${ }^{23} \mathrm{~A}$ separate appendix describes in detail the length of each of the annual time series obtained and the corresponding source.
} 
Australia, Austria, Belgium, Brazil, Canada, Czech Republic, Denmark, Finland, Germany, Iceland, Italy, Japan, Korea, Netherlands, Norway, Portugal, South Africa, Sweden, Thailand, United Kingdom, United States.

It should be remarked that our database includes some cases that deserve comment. For example, it includes Australia for which we obtained pension assets time series corresponding to the sum of both mandatory and voluntary pensions but we could not find separate series for each of them. It also includes countries such as Japan, Canada, Korea, Philippines and Panama for which we found just a fraction of pension assets. Finally, it also includes the case of Netherlands. Although we consider it voluntary because there is no legislation on the contrary, some people consider it mandatory because pension plans are the result of collective labor agreements.

The old dependency ratio, odr, is defined as the number of people older than 65, op, divided by the number of people in working age (people older than 15 and younger than 65), mp. The young dependency ratio, $y d r$, is defined as the number of people younger than 15, yp, divided by the number of people in working age, mp. The urbanization ratio, ur, is defined as the ratio between the number of people living in urban areas, up, and total population, tp. Annual time series of each of the variables were obtained from The World Development Indicators.

The terms of trade, tot, is an index that shows the national accounts exports price index divided by the imports price index, with 1995 as base year. Annual time series of tot for each country were obtained from The World Development Indicators.

Per capita gdp, $p c g d p$, is defined as per capita gdp at constant prices 
measured in dollars of 1995. gdp growth, growth, is defined as real per capita gdp growth rate. The real interest rate, $r$, is the lending rate adjusted for the rate of growth of the $g d p$ deflator. Inflation, inf, is measured as the growth rate in the consumer price index. Annual time series of each of the variables were obtained from The World Development Indicators.

Financial deepening, $f d$, is defined as time and saving deposits, tsd, divided by gross national disposable income, gndi. Edwards (1996) uses M2/GDP for this variable. In our case we cannot use that variable because M2 is no longer a meaningful concept in euro countries. ${ }^{24}$ The foreign saving ratio, $f s r$, is defined as foreign saving (i.e., minus the current account, $c a$ ) divided by gross national disposable income, gndi. Annual time series of each of the variables were obtained from The World Development Indicators.

The social expenditure ratio, ser, is defined as social expenditure, se, divided by gross national disposable income, gndi. Annual time series of social expenditure were obtained from The Government Financial Statistics.

We will start our empirical analysis of the effects of pension saving on national saving by running a simple regression model exploiting both cross country and time variability. The total number of observations is 472 . The estimated equation is ( $\mathrm{t}$ statistics in parenthesis):

$$
n s r=\underset{(50.38)}{.22}-\underset{(-.65)}{.06} \mathrm{psr}
$$

These results suggest show that there is a negative correlation between national saving and pension saving but it is not statistically significant.

\footnotetext{
${ }^{24}$ The reason is that currency, a component of M2, cannot longer be associated to a particular country.
} 
Given that our sample includes countries with mandatory funded pension programs and countries with voluntary funded pension programs, it might be useful to run separate regressions for each group of countries to verify if there is any qualitative difference between both group of countries. The total number of observations for countries with mandatory funded pension programs is 171 . The estimated equation is ( $t$ statistics in parenthesis):

$$
n s r=\underset{(18.39)}{.18}+\underset{(5.34)}{1.51 p s r}
$$

We see that there is a positive correlation between $n s r$ and $p s r$ that is statistically significant. The total number of observations for countries with voluntary funded pension programs is 301 . The estimated equation is $(\mathrm{t}$ statistics in parenthesis):

$$
n s r=\underset{(63.70)}{.23}-\underset{(-6.39)}{.47} p s r
$$

We now see that there is a negative correlation between $n s r$ and psr that is also statistically significant.

Table 1 shows sample statistics for all the variables that will be used in the regressions for the countries where pension funds are the result of a voluntary program. Table 2 shows sample statistics for countries where pension funds are the result of a mandatory program. Note that demographic features differ substantially between both groups of countries. Moreover, national saving rates are much more volatile for countries where pension funds are the result of a mandatory program.

Table 3 shows the matrix of simple correlations for the countries where pension funds are the result of a voluntary program. Table 4 shows sample 
statistics for countries where pension funds are the result of a mandatory program. While the urbanization ratio is negatively related with national saving rates for countries where pension funds are the result of a voluntary program, the opposite happens when we consider countries where pension funds are the result of a mandatory program. We also see that several variables have high correlations among each other which means that multicolinearity issues might be an important obstacle to do statistical inference.

\section{Methods and Results}

We know that a simple correlation between two variables never represents compelling evidence to infer causality between those variables. So our first step to disentangle the effect of pension saving on national saving, on a ceteris paribus sense, will be to control for other national saving determinants that are usually considered in the saving literature.

The natural starting point to do regression analysis is to pool the time series corresponding to each country and estimate the following regression using ordinary least squares, OLS:

$$
n s r=\alpha+\beta p s r+\gamma X
$$

where $\gamma$ is a row vector of coefficients and $X$ is a column vector of controls.

The results of this first regression, R1, are shown in Table 5. We see that pension saving decreases national saving when we hold other national saving determinants constant. We also see that the rest of the coefficients have the signs that were expected. 
The next step is to introduce more flexibility in our estimates and run a regression in which we allow a different slope and a different intercept for the case of countries that have a mandatory funded pension program. To do that we create a new variable, $m$, that takes a unitary value if the country has a mandatory funded pension program and takes a zero if the country has a voluntary funded pension program. We then estimate the following regression:

$$
n s r=\alpha_{0}+\alpha_{1} m+\beta_{0} p s r+\beta_{1}(p s r * m)+\gamma X
$$

where $\alpha_{0}$ denotes the intercept of countries with a voluntary funded pension program, $\left(\alpha_{0}+\alpha_{1}\right)$ denotes the intercept of countries with a mandatory funded pension program, $\beta_{0}$ denotes the effect of an increase in pension saving on national saving for countries with a voluntary funded pension program and $\left(\beta_{0}+\beta_{1}\right)$ denotes the same effect but for the case of countries with a mandatory funded pension program.

The results of this second regression, R2, are shown in Table 5. We verify that mandatory funded pension saving results in an increase of national saving of approximately the same magnitude (i.e., $\beta_{0}+\beta_{1}=1.08$ ). This suggests that there is not much substitution between mandatory pension saving and ordinary saving.

In contrast, voluntary funded pension saving end up in a decrease of national saving. At first glance this is hard to rationalize because it means that voluntary funded pension saving is substituted away by more than $100 \%$. One possible rationalization of this phenomenon is that a full offset of pension saving by adjusting ordinary saving generates a fall in fiscal revenues. In fact, 
voluntary pension funds are typically subject to a special tax treatment. If that is the case, the portfolio reallocation (with no change in private saving) results in a fall in government and national saving. ${ }^{25}$

Now we estimate the previous regression, R2, including ser as one of the regressors. The results of this third regression, R3, are shown in Table 5. The reason for presenting two regressions that are identical except for one variable is that this variable is associated to a loss of 121 observations. We do not like to lose observations due to other variables other than our main variable of interest (i.e., pension saving).

We can check that almost non of the qualitative results change indicating that our previous estimates are quite robust. The only exception is the inflation rate that becomes significant at a 10 percent level. The social expenditure variable has the sign that was expected.

To reinforce the result that voluntary saving incentives do not increase national saving we add the insurance saving ratio, $i s r$, as a new regressor in R4. The new variable is defined as the change in the value of the financial assets reserves, $i a$, from the insurance companies divided by gross national disposable income. ${ }^{26}$ The results of this new regression show that insurance saving is not statistically significant and this is in line with our previous

\footnotetext{
${ }^{25}$ We run the same regression leaving Australia out of the sample and none of the results change. We also run the same regression considering both Australia and Netherlands as mandatory and the results remain almost invariant.

${ }^{26}$ Ideally, we should have used changes in reserves of life insurance companies (who are the providers of long term saving instruments) but data limitations forced us to use data for all type of insurances instead. The sources of this variable are specified in the same appendix where we specify the sources of pension assets.
} 
findings. There no major changes with the rest of the variables.

One typical objection made to regressions like $\mathrm{R} 2$, is that when they include several controls, they are still leaving aside unobserved heterogeneity in the form of time specific effects and country specific effects. To cope with that unobserved heterogeneity we next include year dummies and country dummies. ${ }^{27}$ The estimated equation is:

$$
n s r_{i t}=\alpha_{0}+\alpha_{1} m+\beta_{0} p s r_{i t}+\beta_{1}(p s r * m)+\eta_{i} z_{i}+\delta_{t} t+\gamma X
$$

where $z_{i}$ is a variable that takes a unitary value for country $i$ and a value of zero otherwise, and $t$ denotes the value of calendar time.

The results of this fifth regression, R5, are shown in Table 5. We see that the young dependency ratio, the urbanization ratio, the real interest rate and time and saving deposits ratio are no longer significant, but the inflation rate is significant and positive. The per capita gdp level is significant at a $10 \%$ level. Other interesting features of the regression are that voluntary funded pension saving is no longer significant while mandatory funded pension saving is still significant and with the expected sign. However, the value of the estimated coefficient of psr.m suggests a substantial substitution between mandatory funded pension saving and ordinary saving that was not captured in R2.

Another problem with regression R2 not addressed in R5 is that some of the controls that we have included might be simultaneously determined

\footnotetext{
${ }^{27}$ Our database for Panama, Japan, Canada, Korea and Philippines did not cover the whole universe of pension assets as it does for the rest of the countries. This is an unobserved heterogeneity and is captured by each country dummy.
} 
with national saving. In fact, per capita gdp growth, the real interest rate and foreign saving are usually considered endogenous variables. In that case, OLS estimators are neither unbiased nor consistent.

The most common strategy to deal with this problem is to adopt an instrumental variables, IV, approach to conduct the estimations. We will instrument for each of the potentially endogenous variables (i.e., $r, f s r$ and growth) using the first lag of each variable as instrument. Moreover, we will include country dummies and year dummies. The estimated equation using two stage least squares, 2SLS, is R6 and is shown in Table 5 .

In comparison with R5 we now have that the old dependency ratio and the inflation rate are no longer significant. However, financial deepening is now significant. Again, voluntary funded pension saving continues being non significant while mandatory funded pension saving remains significant and positive. The value of the estimated coefficient of psr.m suggests a slightly smaller substitution than the one that we saw in R5.

Finally, we will estimate a model in which we allow for dynamics by introducing lags of the explained variable as one of the regressors. The model includes a country specific effect and year dummies. To conduct the estimation we will follow the generalized method of moments, GMM, methodology pioneered by Arellano and Bond (1991).

Each of the regressors might be classified as strictly exogenous, predetermined or endogenous. We take all regressors as strictly exogenous with the exception of $n s r_{-1}, r, f s r$ and growth that are considered endogenous. To allow for a richer dynamic structure we also include $r_{-1}, f s r_{-1}$ and $g r o w t h_{-1}$ as additional regressors. 
Ideally we should use the two-step GMM estimator because it is more efficient when the size of the sample is arbitrarily large. However, Arellano and Bond (1991) recommend using the one-step results for inference on the coefficients. Several studies have found that two step standard errors tend to be biased downwards in small samples. For this reason, the one-step results are generally recommended for inference.

The results of this fourth regression, R7, are shown in Table 5. We can see that demographic variables are not statistically significant and the same happens with the real interest rate, the inflation rate and time and saving deposits ratio. All the remaining variables are statistically significant and have the expected signs. The only exception is the urbanization ratio that has a positive sign. As said above, previous studies suggest that its sign should be negative.

One possible explanation for this outcome is that the urbanization process is associated to a weakening of the family contract under which sons take care of their parents when they are old. If that is the case, the expected sign should no longer be negative. The regression suggests that saving history, captured by lagsr, is a key determinant of $n s r$ as we can see from the value of the coefficient. In relation to our main variable of interest $p s r$, we have that voluntary funded pension saving is not significant and the opposite happens with mandatory funded pension saving. Moreover, the value of the coefficient is in line with our previous regressions since in the long run its value would be $.22 / .3=.73$.

We cannot reject the hypothesis that the model is correctly specified. In fact, the p-value of the Sargan specification test is 0.43. As Arellano and 
Bond (1991) emphasize, the presence of first-order autocorrelation in the differenced residuals does not imply that the estimates are inconsistent, but the presence of second-order autocorrelation would imply that the estimates are inconsistent. Fortunately, we cannot reject the hypothesis of no second order autocorrelation since the p-value of the relevant $\mathrm{z}$ statistic is 0.72 .

\section{Conclusion}

In this paper we raised the hypothesis that pension saving might stimulate national saving. Using an unbalanced panel of 43 countries we found evidence suggesting that pension saving increases national saving when pension saving is mandatory. Moreover, we found that each additional dollar of mandatory pension saving increased national saving by more than 50 percent of the increase in mandatory pension saving. We also encountered evidence suggesting that voluntary pension saving (either in the form of pension saving or in the form of insurance saving) does not have a significant effect on national saving.

Which is the mechanism through which mandatory pension saving might foster national saving? First, the development of pension saving schemes, or contractual saving in general, generate a better functioning of capital markets that may itself contribute to higher saving. Second, a funded system with more direct link between contributions and benefits may also increase saving by generating awareness of the importance of saving. Third, individuals might consider mandatory pension saving as an imperfect substitute of ordinary saving due to liquidity considerations. In fact, pension benefits are 
received as an annuity and not as a fixed sum at retirement and thus, has lower liquidity. Fourth, individuals might consider mandatory pension saving and ordinary saving as perfect substitutes but many individuals might be forced to accumulate more assets than they would otherwise choose to do and have trouble to offset pension accumulation (e.g., borrowing constraints). Finally, individuals might follow rules of thumb to decide their levels of ordinary saving that are unaffected by forced saving and therefore increase total saving.

We would like to close by saying that the fact that we found that mandatory contribution to funded pension plans increase national saving does not imply that we suggest that the contribution rate should be considered as a policy instrument to increase national saving. The contribution rate to a mandatory saving plan should be determined by the desired policy decision to secure a minimum replacement rate at retirement (i.e., to prevent old age poverty of the working population). 


\section{References}

Ando, A. and F. Modigliani, 1963, The Life Cycle Hypothesis of Saving: Aggregate Implications and Tests, American Economic Review 53, 55-84.

Arellano M., and S. Bond, 1991, Some Tests of Specification for Panel Data: Monte Carlo Evidence and an Application to Employment Equations, Review of Economic Studies 58: 277-297.

Atkinson, A. and J. Stiglitz, 1980, Lectures on Public Economics, Mc Graw Hill.

Azariadis, C., 1996, Intertemporal Macroeconomics, Basic Blackwell.

Baillu, J., and H. Reisen, 1997, Do Funded Pensions Contribute to Higher Aggregate Savings?: A Cross Country Analysis, OECD Development Centre, Technical Papers 130.

Barro, R., 1978, The Impact of Social Security on Private Saving, American Enterprise Institute for Public Policy Research, Washington, D.C..

Besley T. and C. Meghir, 1998, Tax Based Savings Incentives, Mimeo.

Cagan, P., 1965, The Effect of Pension Plans on Aggregate Saving: Evidence from a Sample Survey, NBER, New York.

Carrol, C., 1997, Buffer-Stock Saving and the Life Cycle/ Permanent Income Hypothesis, Quarterly Journal of Economics 112, 1-55.

Congressional Budget Office, 1998, Social Security and Private Saving: A Review of the Empirical Evidence, U.S. Government Printing Office, Washington, D.C..

Diamond, P., 1965, National Debt in a Neoclassical Growth Model, American Economic Review 55, 1126-1150.

Dynan K., Skinner J. and S. Zeldes, 2003, Do the Rich Save More?, 
forthcoming in The Journal of Political Economy.

Edwards, S., 1996, Why are Latin America's Saving Rates so low? An International Comparative Analysis, Journal of Development Economics 51, $5-44$.

Engen, E., and W. Gale, 1997, Effects of Social Security Reform on Private and National Saving, in Sass, S. and R. Triest, Eds., Social Security Reform: Links to Saving, Investment, and Growth, Federal Reserve Bank of Boston, 103-42.

Feldstein, M., 1974, Social Security, induced retirement and aggregate capital accumulation, Journal of Political Economy 82, 905-26.

Feldstein, M., 1980, International differences in Social Security and Saving, Journal of Public Economics 14, 225-244.

Feldstein, M., 1996, Social Security and Savings: New Time Series Evidence, National Tax Journal 49, 151-164.

Feldstein, M. and Liebman J., 2001, Social Security, NBER Working Paper 8451.

Feldstein, M. and A. Pellechio, 1979, Social Security and Household Wealth Accumulation: New Microeconometric Evidence, Review of Economics and Statistics 61, 361-368.

Flemming, J., 1973, The Consumption Function When Capital Markets are Imperfect: The Permanent Income Hypothesis Reconsidered, Oxford Economic Papers 25, 160-172.

Gale, W., 1998, The Effects of Pensions on Household Wealth: A Reevaluation of Theory and Evidence, Journal of Political Economy 106, 703-723. Government Financial Statistics. Several Issues. 
Hubbard, G., 1986, Pension Wealth and Individual Saving: Some New Evidence, Journal of Money Credit and Banking 18, 167-178.

Impavido, G., Musalem A., and T. Tressel, 2003, The Impact of Contractual Savings Institutions on Securities Markets, Policy Research Working Paper 2948, World Bank.

Katona, G., 1965, Private Pensions and Individual Saving. Ann Arbor: Univ. Michigan, Survey Research Center, Institute for Social Research, The University of Michigan.

Kohl R. and P. O'Brien, 1998, The Macroeconomics of Ageing, Pensions and Savings: A Survey, OECD Economics Department Working Paper 200.

Kotlikoff, L., 1979, Testing the Theory of Social Security and Life Cycle Accumulation, American Economic Review 69, 396-410.

Kotlikoff, L. and L. Summers, 1981, The Role of Intergenerational Transfers in Aggregate Capital Accumulation, Journal of Political Economy 89, 706-732.

Leff, N., Dependency Rates and Saving Rates, American Economic Review 59: 886-896.

Leimer, D. and S. Lesnoy, 1982, Social Security and Savings: New Time Series Evidence, Journal of Political Economy 90, 606-629.

Loayza, N., K. Schmidt-Hebbel, and L. Serven, 2000, What Drives Saving Around the World, Review of Economics and Statistics 82: 165-181.

Loayza, N., Lopez, H., Schmidt-Hebbel K., and L. Serven, 1998, The World Saving Database, World Bank manuscript, The World Bank, Washington, DC.

Masson, P., Bayoumi, T. and H. Samiei, International Evidence on the 
Determinants of Private Saving, World Bank Economic Review 12: 483-501.

Modigliani, F., 1974, The life cycle hypothesis of saving and intercountry differences in the saving ratio, in: W.A. Etlis et al.,eds., Induction growth and trade, Essays in honor of Sir Roy Harrod, Oxford University Press.

Munnel, A., 1976, Private Pensions and saving: New Evidence, Journal of Political Economy 84, 1013-32.

Myles, G., 1995, Public Economics, Cambridge University Press.

OECD, 2003, Institutional Investors Statistical Yearbook.

Ogaky M., Ostry J., and C. Reinhart, Saving Behavior in Low and Middle Income Developing Countries, IMF Staff Papers 43: 38-71.

Ostry J., and C. Reinhart, 1992, Private Saving and Terms of Trade Shocks, IMF Staff Papers 39: 495-517.

Rahman, M., 1968, Foreign Capital and Domestic Saving: A Test of Haavelmo's Hypothesis with Cross Country Data, Review of Economic and Statistics 50: 137-138.

Rebelo S., 1992, Growth in Open Economies, Carnegie-Rochester Conference Series on Public Policy, 36: 5-46.

Samuelson, P., 1958, An Exact Consumption Loan Model of Interest with or without the Social Contrivance of Money, Journal of Political Economy $66,467-482$.

Samwick, A., 1999, Is Pension Reform Conducive to Higher Saving?, Mimeo.

Svensson L., and A. Razin, 1983, The Terms of Trade and the Current Account: The Harberger-Laursen-Metzler Effect, Journal of Political Economy 91: $97-125$. 
Thaler, R., 1990, Anomalies: Saving, Fungibility, and Mental Accounts, Journal of Economic Perspectives 4, 193-205.

The Economist, March 25th 2004, Forever young.

World Development Indicators. Several Issues.

Young, A., 1995, The Tyranny of Numbers: Confronting the Statistical Realities of the East Asian Growth Experience, Quarterly Journal of Economics 110, 641-680. 
Table 1: Voluntary Programs

Summary Statistics for Saving Determinants

\begin{tabular}{cccccc}
\hline Variable & Mean & Median & \multicolumn{5}{c}{ Std. Dev. percentile percentile } \\
\hline nsr & 0.22 & 0.2 & 0.05 & 0.17 & 0.25 \\
psr & 0.03 & 0.02 & 0.03 & 0.003 & 0.06 \\
odr & 0.15 & 0.17 & 0.06 & 0.1 & 0.19 \\
ydr & 0.4 & 0.33 & 0.17 & 0.28 & 0.43 \\
ur & 0.79 & 0.83 & 0.14 & 0.74 & 0.88 \\
tot & 101.15 & 100.17 & 7.67 & 98.08 & 102.65 \\
gdp & 21,871 & 23,130 & $9,071.14$ & 18,149 & 27,647 \\
growth & 0.02 & 0.02 & 0.02 & 0.007 & 0.03 \\
r & 0.06 & 0.06 & 0.07 & 0.04 & 0.08 \\
inf & 0.05 & 0.03 & 0.08 & 0.02 & 0.05 \\
fd & 0.38 & 0.36 & 0.16 & 0.27 & 0.45 \\
fsr & 0.005 & 0.009 & 0.03 & -0.02 & 0.03 \\
ser & 0.17 & 0.18 & 0.07 & 0.11 & 0.21 \\
\hline
\end{tabular}

Table 2: Mandatory programs

Summary Statistics for Saving Determinants

\begin{tabular}{cccccc}
\hline Variable & Mean & Median & Std. Dev. percentile percentile \\
\hline nsr & 0.24 & 0.21 & 0.11 & 0.14 & 0.27 \\
psr & 0.03 & 0.019 & 0.028 & 0.01 & 0.049 \\
odr & 0.09 & 0.08 & 0.04 & 0.07 & 0.101 \\
ydr & 0.53 & 0.51 & 0.19 & 0.42 & 0.66 \\
ur & 0.71 & 0.74 & 0.2 & 0.56 & 0.86 \\
tot & 97.71 & 98.31 & 9.78 & 92.31 & 102.57 \\
gdp & $5,891.56$ & $3,488.70$ & $6,688.55$ & $2,048.60$ & $5,543.10$ \\
growth & 0.02 & 0.03 & 0.03 & 0.002 & 0.05 \\
r & 0.1 & 0.08 & 0.1 & 0.04 & 0.12 \\
inf & 0.07 & 0.04 & 0.07 & 0.02 & 0.1 \\
fd & 0.39 & 0.32 & 0.19 & 0.25 & 0.53 \\
fsr & 0.01 & 0.02 & 0.06 & 0.0003 & 0.04 \\
ser & 0.12 & 0.1 & 0.05 & 0.08 & 0.14 \\
\hline
\end{tabular}


Table 3

Cross correlations: voluntary programs

\begin{tabular}{|c|c|c|c|c|c|c|c|c|c|c|c|c|c|}
\hline & $\mathrm{nsr}$ & psr & odr & $y d r$ & ur & tot & gdp & growth & $r$ & inf & $\mathrm{fd}$ & $f s r$ & ser \\
\hline $\mathrm{nsr}$ & 1 & & & & & & & & & & & & \\
\hline psr & -0.39 & 1 & & & & & & & & & & & \\
\hline odr & -0.61 & 0.06 & 1 & & & & & & & & & & \\
\hline$y d r$ & 0.46 & -0.11 & -0.84 & 1 & & & & & & & & & \\
\hline ur & -0.38 & 0.25 & 0.5 & -0.38 & 1 & & & & & & & & \\
\hline tot & 0.24 & -0.01 & -0.31 & 0.49 & -0.11 & 1 & & & & & & & \\
\hline gdp & -0.14 & -0.11 & -0.1 & 0.05 & -0.06 & -0.05 & 1 & & & & & & \\
\hline growth & 0.05 & 0.1 & 0.11 & -0.26 & -0.01 & -0.03 & -0.04 & 1 & & & & & \\
\hline$r$ & -0.3 & 0.09 & 0.09 & -0.15 & -0.18 & -0.09 & 0.09 & 0.03 & 1 & & & & \\
\hline inf & -0.02 & 0.18 & -0.08 & 0.1 & 0.07 & 0.05 & -0.31 & 0.22 & 0.26 & 1 & & & \\
\hline $\mathrm{fd}$ & 0.52 & -0.14 & -0.35 & 0.24 & -0.36 & 0.03 & -0.14 & 0.03 & -0.06 & -0.15 & 1 & & \\
\hline fsr & -0.16 & -0 & 0.42 & -0.11 & 0.51 & 0.05 & -0.13 & 0.17 & -0.37 & -0.08 & -0.26 & 1 & \\
\hline ser & -0.18 & 0.04 & 0.4 & -0.28 & 0.59 & -0.07 & 0.03 & 0.22 & -0.35 & -0.11 & -0.31 & -0.62 & 1 \\
\hline
\end{tabular}

Table 4

Cross correlations: mandatory programs

\begin{tabular}{|c|c|c|c|c|c|c|c|c|c|c|c|c|c|}
\hline & $\mathrm{nsr}$ & $\mathrm{psr}$ & odr & $y d r$ & ur & tot & gdp & growth & $r$ & inf & $\mathrm{fd}$ & fsr & ser \\
\hline $\mathrm{nsr}$ & 1 & & & & & & & & & & & & \\
\hline psr & 0.39 & 1 & & & & & & & & & & & \\
\hline odr & -0.2 & -0.23 & 1 & & & & & & & & & & \\
\hline ydr & -0.16 & 0.03 & -0.62 & 1 & & & & & & & & & \\
\hline ur & 0.25 & 0.3 & 0.18 & -0.58 & 1 & & & & & & & & \\
\hline tot & 0.35 & -0.26 & -0.03 & -0.05 & -0.01 & 1 & & & & & & & \\
\hline gdp & -0.49 & -0.16 & 0.18 & -0.03 & 0.19 & -0.12 & 1 & & & & & & \\
\hline growtl & 0.73 & 0.26 & -0.25 & -0.01 & 0.34 & 0.21 & -0.19 & 1 & & & & & \\
\hline$r$ & -0.73 & -0.11 & 0.12 & 0.32 & -0.34 & -0.25 & 0.25 & 0.6 & 1 & & & & \\
\hline inf & -0.41 & -0.03 & 0.18 & -0.16 & -0.13 & -0.43 & 0.1 & 0.5 & 0.37 & 1 & & & \\
\hline $\mathrm{fd}$ & 0.38 & 0.21 & -0.08 & 0.03 & -0.06 & 0.1 & -0.48 & 0.11 & -0.02 & 0.04 & 1 & & \\
\hline fsr & 0.74 & 0.2 & 0.09 & -0.56 & 0.66 & 0.23 & -0.14 & 0.64 & -0.77 & -0.34 & 0.1 & 1 & \\
\hline ser & -0.43 & -0.01 & 0.62 & -0.3 & 0.25 & -0.37 & 0.39 & 0.21 & 0.38 & 0.4 & -0.17 & -0.15 & 1 \\
\hline
\end{tabular}


Table 5: Panel Regressions Results

\begin{tabular}{|c|c|c|c|c|c|c|c|}
\hline & R1 & $\overline{\mathrm{R} 2}$ & R3 & $\mathrm{R} 4$ & R5 & R6 & R7 \\
\hline psr & $\begin{array}{c}-0.13 \\
{[-2.16]}\end{array}$ & $\begin{array}{c}-0.37 \\
{[-6.11]}\end{array}$ & $\begin{array}{c}-0.53 \\
{[-6.77]}\end{array}$ & $\begin{array}{c}-0.52 \\
{[-5.82]}\end{array}$ & $\begin{array}{l}-0.01 \\
{[0.31]}\end{array}$ & $\begin{array}{c}0.01 \\
{[0.19]}\end{array}$ & $\begin{array}{l}0.01 \\
{[.64]}\end{array}$ \\
\hline odr & $\begin{array}{c}-0.54 \\
{[-8.12]}\end{array}$ & $\begin{array}{c}-0.61 \\
{[-10.30]}\end{array}$ & $\begin{array}{c}-0.54 \\
{[-6.91]}\end{array}$ & $\begin{array}{c}-0.47 \\
{[-4.87]}\end{array}$ & $\begin{array}{c}-0.26 \\
{[-2.55]}\end{array}$ & $\begin{array}{c}-0.13 \\
{[-0.87]}\end{array}$ & $\begin{array}{c}-0.04 \\
{[-0.85]}\end{array}$ \\
\hline$y d r$ & $\begin{array}{c}-0.07 \\
{[-3.10]}\end{array}$ & $\begin{array}{c}-0.12 \\
{[-5.97]}\end{array}$ & $\begin{array}{c}-0.1 \\
{[-4.39]}\end{array}$ & $\begin{array}{c}-0.06 \\
{[-2.03]}\end{array}$ & $\begin{array}{c}-0.02 \\
{[-0.82]}\end{array}$ & $\begin{array}{c}-0.06 \\
{[-1.39]}\end{array}$ & $\begin{array}{l}0.004 \\
{[0.31]}\end{array}$ \\
\hline ur & $\begin{array}{c}-0.02 \\
{[-1.17]}\end{array}$ & $\begin{array}{l}-0.06 \\
{[-4.1]}\end{array}$ & $\begin{array}{c}-0.04 \\
{[-2.11]}\end{array}$ & $\begin{array}{c}-0.03 \\
{[-1.34]}\end{array}$ & $\begin{array}{c}0.11 \\
{[1.20]}\end{array}$ & $\begin{array}{l}-0.06 \\
{[-.43]}\end{array}$ & $\begin{array}{c}0.13 \\
{[2.63]}\end{array}$ \\
\hline tot & $\begin{array}{l}0.0009 \\
{[3.66]}\end{array}$ & $\begin{array}{l}0.001 \\
{[6.67]}\end{array}$ & $\begin{array}{l}0.001 \\
{[5.68]}\end{array}$ & $\begin{array}{l}0.001 \\
{[3.19]}\end{array}$ & $\begin{array}{l}0.001 \\
{[7.41]}\end{array}$ & $\begin{array}{c}0.0008 \\
{[2.81]}\end{array}$ & $\begin{array}{c}0.0004 \\
{[4.03]}\end{array}$ \\
\hline pcgdp & $\begin{array}{c}0.000001 \\
{[4.17]}\end{array}$ & $\begin{array}{c}0.000002 \\
{[6.71]}\end{array}$ & $\begin{array}{c}0.000001 \\
{[3.88]}\end{array}$ & $\begin{array}{c}0.000001 \\
{[2.46]}\end{array}$ & $\begin{array}{c}0.000001 \\
{[1.72]}\end{array}$ & $\begin{array}{c}0.0000004 \\
{[0.25]}\end{array}$ & $\begin{array}{c}0.000001 \\
{[3.46]}\end{array}$ \\
\hline growth & $\begin{array}{c}0.71 \\
{[9.31]}\end{array}$ & $\begin{array}{c}0.59 \\
{[8.67]}\end{array}$ & $\begin{array}{c}0.58 \\
{[7.14]}\end{array}$ & $\begin{array}{c}0.62 \\
{[6.48]}\end{array}$ & $\begin{array}{c}0.3 \\
{[6.51]}\end{array}$ & $\begin{array}{c}1.06 \\
{[4.34]}\end{array}$ & $\begin{array}{c}0.25 \\
{[9.60]}\end{array}$ \\
\hline$r$ & $\begin{array}{l}-0.07 \\
{[2.70]}\end{array}$ & $\begin{array}{c}-0.06 \\
{[-2.75]}\end{array}$ & $\begin{array}{c}-0.11 \\
{[-3.67]}\end{array}$ & $\begin{array}{c}-0.12 \\
{[-3.57]}\end{array}$ & $\begin{array}{l}-0.02 \\
{[-0.9]}\end{array}$ & $\begin{array}{c}-0.05 \\
{[-0.34]}\end{array}$ & $\begin{array}{l}-0.01 \\
{[-.81]}\end{array}$ \\
\hline $\inf$ & $\begin{array}{c}0.03 \\
{[1.11]}\end{array}$ & $\begin{array}{c}0.03 \\
{[1.23]}\end{array}$ & $\begin{array}{c}0.05 \\
{[1.65]}\end{array}$ & $\begin{array}{c}0.05 \\
{[1.47]}\end{array}$ & $\begin{array}{c}0.09 \\
{[3.95]}\end{array}$ & $\begin{array}{c}0.09 \\
{[1.52]}\end{array}$ & $\begin{array}{c}0.01 \\
{[1.28]}\end{array}$ \\
\hline $\mathrm{fd}$ & $\begin{array}{c}0.1 \\
{[8.32]}\end{array}$ & $\begin{array}{c}0.08 \\
{[7.96]}\end{array}$ & $\begin{array}{c}0.11 \\
{[7.82]}\end{array}$ & $\begin{array}{c}0.13 \\
{[7.91]}\end{array}$ & $\begin{array}{l}0.006 \\
{[.52]}\end{array}$ & $\begin{array}{c}0.05 \\
{[2.18]}\end{array}$ & $\begin{array}{l}0.004 \\
{[0.67]}\end{array}$ \\
\hline fsr & $\begin{array}{c}-0.71 \\
{[-12.50]}\end{array}$ & $\begin{array}{c}-0.6 \\
{[-11.97]}\end{array}$ & $\begin{array}{c}-0.57 \\
{[-8.53]}\end{array}$ & $\begin{array}{c}-0.61 \\
{[-7.27]}\end{array}$ & $\begin{array}{c}-0.41 \\
{[-11.19]}\end{array}$ & $\begin{array}{c}-0.23 \\
{[-2.99]}\end{array}$ & $\begin{array}{c}-0.45 \\
{[-18.29]}\end{array}$ \\
\hline ser & & & $\begin{array}{c}-0.08 \\
{[-2.23]}\end{array}$ & $\begin{array}{c}-0.1 \\
{[-2.43]}\end{array}$ & & & \\
\hline isr & & & & $\begin{array}{c}-0.09 \\
{[-0.56]}\end{array}$ & & & \\
\hline$p s r^{*} m$ & & $\begin{array}{c}1.45 \\
{[10.48]}\end{array}$ & $\begin{array}{c}1.55 \\
{[9.47]}\end{array}$ & $\begin{array}{c}1.18 \\
{[5.81]}\end{array}$ & $\begin{array}{c}0.58 \\
{[4.84]}\end{array}$ & $\begin{array}{c}0.64 \\
{[3.81]}\end{array}$ & $\begin{array}{c}0.22 \\
{[4.03]}\end{array}$ \\
\hline lagnsr & & & & & & & $\begin{array}{c}0.7 \\
{[29.32]}\end{array}$ \\
\hline$\overline{\text { R-squared }}$ & 0.65 & 0.73 & 0.76 & 0.69 & 0.92 & 0.85 & \\
\hline Observ. & 445 & 445 & 324 & 269 & 445 & 438 & 358 \\
\hline
\end{tabular}

